\title{
EROTICAL SIGNS IN THE POETRY OF ISMAIL KADARE
}

\section{Prof. Ass. Merxhan AVDYLI}

Public University "Kadri Zeka" Gjilan, Faculty of Education, merxhan.avdyli@uni-gjilan.net

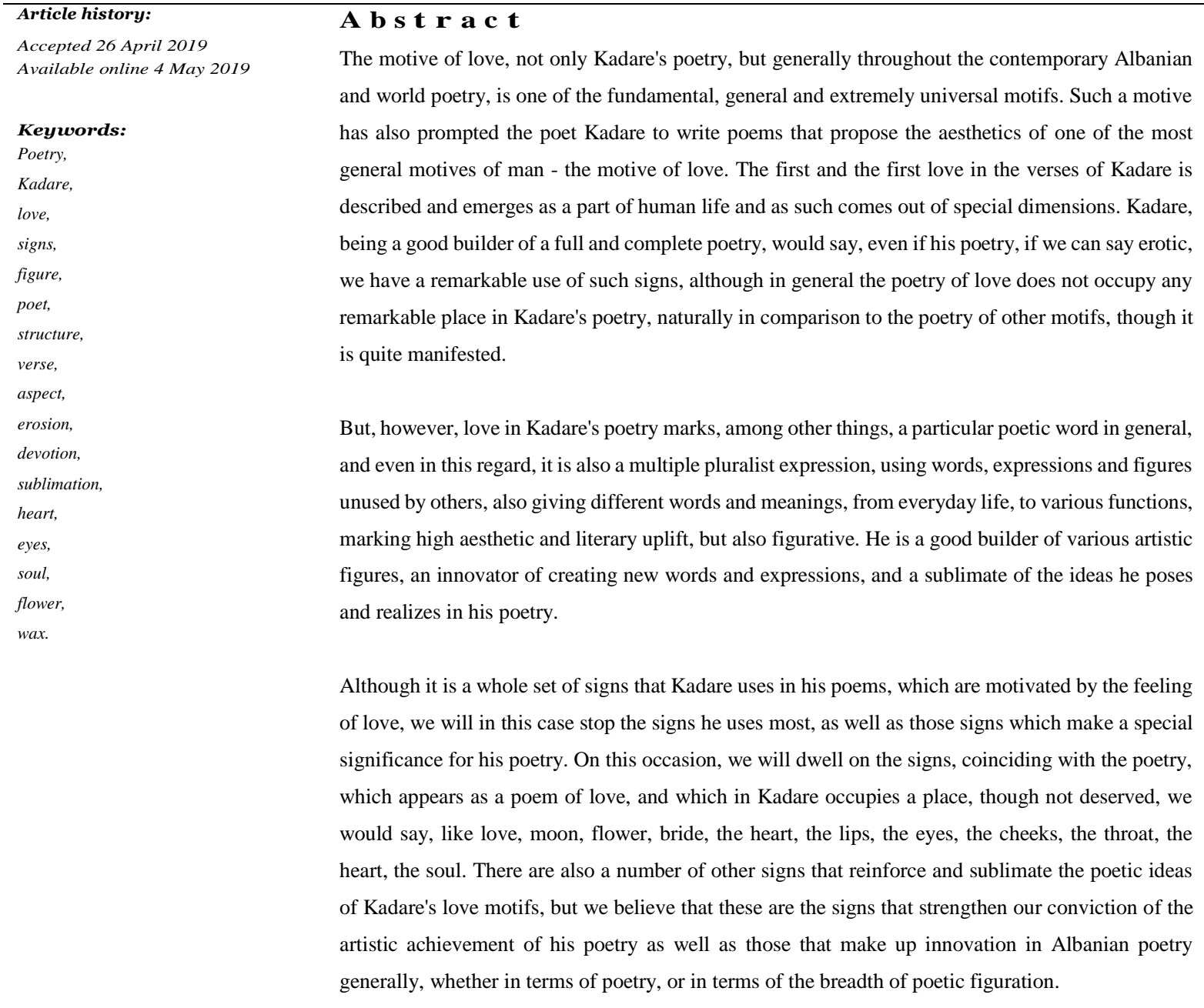

\section{Love (Poetry Eros)}

The most useful word in erotic poetry is to remember that it is love. Even in Kadare's poetry, the presence of the motive of love is expressed, though not significant, as if it is eg. to the poetry of Dritero Agolli.

So, being a special human feeling, love in Kadare's poetry also has special treatment. The sign of love is encountered in a string of poems from the first poems. Even a part of his poems are commitments, we would say concrete, which usually under the title emphasizes who he or she is devoted to, whether by imaginary name or only with initials such as "Helena" "For Helen", "Tanja Velinskajas", "Zh. Burkinas "," B. E. "," B. "," F. "or even the title of any dedicatory poetry such as" Zhana B.", " devoted to V. "," Llora "," Ljudmillë " or even undetermined commitments, written below the title of poetry, such as: "A volunteer", "Letter to a lover", etc. (Kadare, 2005, p. 25). 
Usually poems with a wide range of love signs have a use of other signs, such as girls, flowers, lips, hearts etc., to which Kadare in his poetry is very attentive, using them in complete poetic and aesthetic function.

Although the motive of love comes to a considerable part of Kadare's poetry, however, the very notion itself, in this case, the love sign does not have any meaningful use, of course this in many cases is implied.

With a special function, the love sign appears in the poem "I saw the first flowers ..." in which we have a personification of love, identifying it with a single flower, which does not fade or return. The strings of the last verse are realized, which is in fact the basic idea of poetry:

All the first things will go away

And yet they will come back.

In addition to the first love:

She does not flip it, nor does she come back. (Kadare, 1957, p.19)

Love, as a concept that the author usually understands as a high individual human value, also appears in some poems, which are written, whether at different times, even in different places, even for flirtations, if we can say, the author's love to a certain time, indefinitely. Such are also poems such as "You" (Kadare, 1990, p. 44), "Zhana B" (Kadare, 2008, p. 61), "Berjoza" (Kadare, 1997, p. 9), "Llora" (Kadare, 1990, pp. 50-57), "Ljudmilla" (Kadare, 1957, p. 30) and some others.

Meanwhile, a more concentrated focus on love, in artistic and literary terms, but not only so, but also human, we have the ballad "Flute", which even in the author's own note below her title writes: "Ballad for love and jealousy. "Balada is the focus of attention on Tanna's love, which is also the lion's hero of the ballad. It is her feminine intuition, that is, of a loving lover, who through the sounds of the flute sounds the sensations of love when the author addresses it:

And every night for love

You hear the flute you say

You know, no sound shed tears. (Kadare, 1957, p. 70)
The further elaboration of the ballad events is tragic, as Tana fails to marry the shepherd who had been killed by the kacams, while she committed suicide by leaking from the bed. Otherwise, ballad "Juraja" is one of Kadare's most accomplished ballads in which love and jealousy are two contradictory life segments that bring the tragic end to this excellent ballad.

Kadare's poetic power is also felt in this motivational type of poetry, or poetry of love, since through various poetic figures, in the concrete case of comparison, he also creates different pictures. Since in love-motivated poetry we do, not rarely with memories, Kadare's dedicating poetry "Llora" (Kadare, 1990, p. 40). Here is an interesting picture of the first part of this long poetry that is more or less stuck with the poem where the author addresses Lloré, with these words and thus:

Lora,

You remember Lora again.

Our past love

Again chew

As a bull rearing the grass of remote meadows

at night

In the cob surrounded by snow. (Kadare, 1990, p. 50)

But we have another aspect of love - the fear of it, which Kadare brilliantly describes the fear of love, of different categories of people. The lines of poetry, which in its title bear the mark of love, which is simply titled "Love", represents the decline in the power of love, of those to whom it also refers to love itself:

They are afraid of you. Oh, how are they afraid?

Elderly with wrinkles full of faces, which neither the beast nor the bullet either fears

Borsaline men and bags that are often called in the gathering,

Women who were bravely braved deaths;

They are afraid of you. (Kadare, 1976, p. 192)

Not only when we are dealing directly with the feelings of love that Kadare reveals through his verses, but in one case goes beyond this, because he also writes verses for the very words of love, as is the case with the poem "The words of love "Which is inspired by the verses of the Russian poet Lermontov, an inspiration that Kadare functions in a lyrical love of words of 
love, which, at the right moment, leave him, as in the following verses:

\section{$\mathrm{O}$ words of love}

Do the fuck

Just before you leave me alone

What did you do to me?

Where did the tongue tie me up,

Look at the legs

Birds like a hunter,

That left you scared. (Kadare, 1957, p. 35)

It should be noted here that the sign of love, poetry of Kadare, as well as poetry in general, is not used only as love in the sense of eros, but also as love in a broader, more general sense, or as a love of homeland, as a love for the family, or even as a love of people, as a love in an altruistic, human sense. But, in this case, they were not part of this treatment.

\section{The Girl (wigs, lazy, youth, love)}

One of the main signs, which fills the main motto of lovemotivated poetry, is the girl, namely the dresser. And in this light, Kadare's poetry is motivated by love for a woman and hence does not hesitate to write, even poetry devoted to any woman she loves or for which she has felt the pangs of heart.

In all periods of Kadare's poetry writing, we have a good and significant representation of the girl's signature, namely the wax, which is presented through various stylistic figures. Meanwhile, the sign is sometimes used in poems that are not motivated by love, but have other motives, for example. poetry "The First Parachutists"(Kadare, 1978, p. 109) (the verse "Four daughters will descend to the earth, from the floors of the sky").

Perhaps there is also an unwritten rule that feelings of love appear most in the period of youth, so poetry motivated by love for women is more present in the early period of Kadare's poetry. Although love does not recognize age limits, however, youth is somehow the most suitable bed for her. Likewise, with this show of feeling, though not always, we have the use of the sign of the girl, who is very present in the first phase of his poetic writings, namely in the poetic volumes of Calf inspirations and dreams, but later on the others, more or less. The treatment of the signs of the girl and the maid will become common since there are two synonymous words. Meanwhile, Kadare uses his poetry in the same sense, depending on the style and place used, either because of the rhythm or poet's intonation, but not because of emotional colorings, since both of them have the same emotional shades, as well as the same motivational star. He even uses the trimming of the lover's name as a lullaby. Thus he, through the stylistic figure of thought-lithoth, to the "Good-bye" (Kadare, 1954, pp. 7-9) poetry, calls his girlfriend with a cuddly cuddle.

There are a variety of poems with love motifs, which we always use for the love of the girl's sign, as well as the summaries of the dreams, such as the poems: "Ballad", "The Fall of Autumn", "The River Coast", "Spring Come again, "' O this side of the river, "' The whistle of the whistle, "" The joyous song, "etc. The poems in which we have the appearance of the girl are lyricism that has many emotional burdens of love, but these poems are more of a sometimes platonic love than any concrete love as it happens, for example. in cases where we have more specific erotic descriptions, where erotic areas are distinguished eg. lips. Therefore, in these poetry of Kadare, the girl does not speak but sings on her own, though she is sometimes playful and sometimes saddened by puddles, but she is sometimes close to the lyrical hero, when the author of poetry "The Whip" Express:

There came a cool evening, calm autumn came,

With a girl lying on the side, a lofate.

The beautiful girl, the starry sky adorned;

Beyond the whistle song the forest had abandoned. (Kadare, 1957 , p. 33)

Generally, the girl in Kadare's poetry is a sign that is largely identical to love, even with a sincere and extremely low-profile love, a love that rarely breaks the boundaries of first acquaintance with a youthful and healthy love.

\section{The Bride (crowning love, weddings, new life)}

The other sign of love is especially used in a part of Kadare's ballads, but also in poems of other forms. The bride's signature is usually related, sometimes even in complete dependence with the wedding sign, which is more of an ethnographic sign, perhaps identity, because of the specialty of the Albanian wedding, but it is also related to the groom, since it will naturally it was somewhat pointless to marry the bride from the groom. Even, almost every time we have a coexistence of the wedding trinity the bride-groom, which signs have a causal connection.

"Brides and daughters" is a poem which is best seen in any other poetry of Kadare, an interesting Albanian wedding picture, where we have a description of it, then the Albanian brides that are "dressed in pieces stars, "" meteorites "and Albanian weddings in the autumn, because" the winter of wars came ", as Kadare says. 
Thus, while the initial description for brides starts when, on the one hand, they are:

Mist-coated

With broken pieces

The brides of the provinces

Albania. (Kadare, 1976, p. 31)

Meanwhile, on the other hand, the lyrical subject itself, becoming part of this beautiful lyrical, states:

As in the pollen of flowers,

Since sprinkle everything,

Something from the starship bride

Over the shoulders of the ra. (Kadare, 1976, p. 31)

Of the same theme is the other poetry "Brides with Veil", although there is a more pronounced drama in itself. In this poem the bride's sign is used in a very different function, compared to the poet quoted above. Meanwhile, the dramatic culmination is reached in strings, as follows:

Veil covered the face of the bride

As the drapery covers a drama. (Kadare, 1978, p. 37)

\section{The Heart (physical love and Platonic love)}

The heart, as a concrete physical body of man, but also as a metaphysical element, was used in poetry of Kadare to reinforce the ideas of his love poetry. In this spirit, the heart becomes ever clean, soft and ready to strengthen the element of love in Kadare's poetry, though it does not have any significant use. Although there are occasions when the heart of Kadare's poetry uses other figurative meanings outside the backdrop of erotic poetry, here we will only address the use of erotic erotic heart markers. Moreover, the heart is especially used in poetry of patriotism, such as. to the poem "Homeland"(Kadare, 1954, p. 3-4) or to any other.

Kadare achieves that through the heart mark, not only create powerful stylistic figures, but also create different looks that seem to be close to her or entirely within her. It is especially significant to create the poetic atmosphere of poetry "Enter without fear", where the poet gives the girlfriend's orientation to enter into his heart, where it is only her. The following verses:

Enter without fear in my heart,

As in a dark salon,

Do not hold a torch in your hand

That does not have to collide with this
In the dark. (Kadare, 2008, p. 102)

Even in the poem "Song of Miller" (Kadare, 1978, pp. 52-55), which is an inspiration from popular poetry, the heart here is put into the function of the love ties between the village girl and the new miller.

The heart of miller, says Kadare will join the petes, which his bride will cook. In fact, all poetry focuses on the heart of miller, which as such is great, a heart that can not poison the bride, a heart that is even ready to withstand grinding.

\section{Lips (fire of love, kiss)}

Another physical body, which in an erotic sense is an erogenous area that fosters the feelings of love and used in the poetry of Kadare's love, are the feminine lips, which Kadare describes as a flash of love feelings.

But, not always, the poetry of Kadare's lips expresses their expected heat. Thus, in the poem "Last Night", during the description of the moment of division, the lyric hero states:

\section{We kissed}

Lips like metal. (Kadare, 1961, p. 49)

Meanwhile, on the other hand, in the poem "When to Call", depicting the phone call with the girlfriend Kadare heroic hero, who in this case may be the author himself, the feelings of love emerge through two erotic symbols: hair and lips, as in the verses where it rains constantly, as in many verses of Kadare, as in the following verses:

Outside it rained.

I gratefully appreciated the long phone wires.

They came from afar, without stopping right from you,

From the smell of your hair, from the loyal line of lips,

Without pausing, without pleading

With glamorous rainbows on the road. (Kadare, 1978, p. 71)

\section{References}

1. Aliu, A. - Sh. Sinani, S. Çapaliku, T. Chobani, Letërsia bashkëkohore shqiptare (Contemporary Albanian Literature), Albas, Tirana-Tetovo, 2002.

2. Avdyli, Merxhan, Sprova zbuluese të poetikës (The exploration of poetry), Brezi 81, Pristina, 2005 . 
3.

Bart, Rolan, Književnost, mitologija, semiologija (Literature, Mythology, Semiology), Belgrade, 1971.

4. Eco, Umberto, Si bëhet një punim diplome (How to Become a Diploma), "Attempt", Tirana, 1997.

5. Fjalor i mitologjisë (Dictionary of Mythology) Prepared by: Todi Thamo, "Rilindja", Prishtina, 1988.

6. Kadare, Ismail, Ëndërrimet..., lirika dhe poema (Dreaming ...), Ndërmarrja Shtetërore e Botimeve, Tiranë, 1957.

7. Kadare, Ismail, Frymëzimet djaloshare, lirika (Inspiration to the boy), Ndërmarrja Shtetërore e Botimeve, Tiranë, 1954.

8. Kadare, Ismail, Ftesë në studio, poezi, shënime (Invitation to the studio, poetry, notes), "Naim Frashëri", Tirana, 1990.

9. Kadare, Ismail, Koha, vjersha dhe poema (Time), "Naim Frashëri", Tirana, 1976.

10. Kadare, Ismail, Motive me diell (Sunni motives), "Renesanca", Prishtina, 1978.

11. Kadare, Ismail, Pa formë është qielli (Without form is the sky), “Onufri”, Tiranë, 2005.

12. Kadare, Ismail, Përse mendohen këto male, vjersha dhe poema (Why are these mountains), "Naim Frashëri", Tirana, 1964.

13. Kadare, Ismail, Poezi (Poetry), "Naim Frashëri”, Tiranë, 1976, f. 192.

14. Kadare, Ismail, Shekulli im, vjersha dhe poema (My century), “Naim Frashëri”, Tiranë, 1961.

15. Kadare, Ismail, Vepra, vëllimi 7 (Works, vol. 7), "Onufri", Tirana, 2008.
16. Lotman, J. V., Predavanja iz strukturalne poetike (Lectures from structural poetics) "Matica Hrvatska", Zagreb, 1965.

17. Lotman, J. V., Struktura umetničkog teksta (Structure of the Art Text), "Nolit", Belgrade, 1976.

18. Raifi Mensur, Mbi poezinë bashkëkohëse shqipe (On Contemporary Albanian Poetry), "Rilindja", Prishtina, 1977.

19. Slamnig, Ivan, Disciplina mašte (Discipline of imagination), Zagreb, 1971.

20. Vinca, Agim, Orët e poezisë (Poetry Hours), "Rilindja", Prishtina, 1990.

21. Welek, Rene - Austin Warren, Teoria e letërsisë (Theory of Literature), "Onufri", Tirana, 2015.

22. Zhenet, Zherar, Figurat (Figures), "Rilindja", Prishtina, 1985. 